\title{
Academicians' And Practitioners' Views On The Importance Of The Topical Content In The First Auditing Course
}

Jack Armitage, University of Nebraska at Omaha, USA Jillian K. Poyzer, BKD, LLP, Omaha, NE, USA

\begin{abstract}
The research question addressed in this study is to compare and identify differences between academics teaching auditing classes and practicing accountants regarding the importance of topics covered in the first university auditing course. This is accomplished by surveying academics and practitioners regarding their perceptions of the importance of 41 topics addressed in current auditing textbooks. The results show the five most important topics, as ranked by professors, are audit risk, understanding internal control, evidence, financial statement assertions, and fraud awareness. The five most important topics as ranked by accounting practitioners, are audit risk, ethics, documentation, understanding IC, analytical procedures. Professors teaching auditing classes face a challenge ensuring they prepare students to enter the business world equipped with all the skills necessary to be successful. Auditing professors should give consideration to tapping into this wealth of knowledge provided by accounting professionals and reevaluate the emphasis in their current auditing class.
\end{abstract}

Keywords: auditing, education, survey, academic's views, practitioner's views

\section{INTRODUCTION}

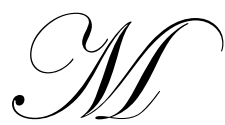

any changes have occurred in the accounting profession in recent years. Corporate scandals have put a new light on accounting, the proliferation of new authoritative standards, and the 150-hour requirement to sit for the CPA exam create a challenge for academics to develop an accounting curriculum that can prepare future practitioners for success. The future health of the accounting profession depends, to a great extent, on the success of our students (Gorman, 2005). To prepare students to succeed requires an accounting curriculum that is relevant and includes the topics students should be exposed to during their university education. The responsibility to maintain the health of accounting curricula falls on professors at colleges and universities, but input from practicing accountants is very useful. Professors must maintain currency with changes in the accounting profession and incorporate those changes into the curriculum in order to prepare students to enter successful accounting careers. Practicing accountants provide an excellent source of information regarding the knowledge necessary to succeed in the profession.

The research question addressed in this study is to compare and identify differences between academics teaching auditing classes and practicing accountants regarding the importance of topics covered in the first university level auditing course. This is accomplished by surveying academics and practitioners across the United States regarding their perceptions of the importance of 41 topics addressed in current auditing textbooks.

\section{LITERATURE REVIEW}

Much has been written regarding accounting education and how it should change to meet the needs of the profession, as was well chronicled by Albrecht and Sack (2000). However, there is a more limited body of literature specifically examining the auditing course in college and university curricula, and relatively few studies that have 
examined the importance professors and practicing accountants place on specific topics in auditing courses.

An analysis done by members of the 2000-2001 Auditing Section Education Committee showed significant changes in accounting and auditing education over the past twenty years. (Johnson et al., 2003) They examined several audit course surveys and found increases in fraud, technology-related topics, and internal control concepts in auditing classes. The Committee also gathered over 250 audit course syllabi from 188 colleges in 2001 and analyzed the different topics covered. They found heavy weight on topics such as audit planning (96\%), internal control (96\%), audit evidence (94\%), audit reports (92\%), and professional standards $(92 \%)$. The Committee also found ethics that included references on independence in $84 \%$ of the courses and fraud awareness in $42 \%$ of the curriculum.

McCartney et al. (2002) investigated whether a gap exists between academic content and practitioner needs for internal auditing in the USA. A questionnaire survey was used to gather data from auditing faculty and practitioners to determine the importance of 25 different internal auditing topics. There was agreement in some areas, but educators placed more importance on engagement planning, preliminary surveys, audit programs, risk management, and fraud. Practitioners placed more importance on qualities desired in staff internal auditors, CIA examination preparation, and computer auditing. The McCartney et al. paper is similar to the study reported in this paper except the McCartney et al. paper focused on the study of internal auditing rather than external auditing so the topics are not comparable to courses that focus on external auditing.

Another paper involving practitioners' views on accounting education was Novin (1997). This paper examined the similarities and dissimilarities of academic subjects needed for careers in management accounting, auditing, and tax. The paper was based on a survey of practitioners and reported that the study of taxation, statistical sampling, business law, and not-for-profit accounting are more important for auditors than for managerial accountants.

Gramling et al. (1996) used a survey questionnaire to study the role of undergraduate auditing coursework in universities in reducing the expectations gap. Many significant differences between views of students and practicing auditors were found including the auditor's responsibility to detect fraud, prohibitions and regulations on audit firms, groups to whom auditors should be responsible, and the auditor's role with respect to audited financial statements. This study used practitioners' views for comparison purposes as does the study reported in this paper except it used the views of students to compare with practitioners' views rather than the views of the professors that design and deliver the course, and it focused on the expectations gap rather than examining the importance of topics included in the class.

Two papers, Engle and Elam (1985) and Bryan and Smith (1997), examined the importance placed on selected auditing topics by academics, but did not include the views of practitioners. Bryan and Smith (1997) surveyed auditing professors to ascertain their perceptions of the importance of 31 auditing topics. The results found widespread agreement across academic ranks and school's accreditation status, on many topics. The five most important topics were generally accepted auditing standards, audit risk and materiality, internal control structure, type and competence of evidence, and the standard audit report. Engle and Elam (1985) examined the extent of coverage of 36 topics in auditing courses by obtaining information on the class time allocated to each topic by using a survey questionnaire. Their study found the five most important topics to be internal control structure, standard audit report, designing and performing substantive tests, types and competence of evidence, and auditors' professional responsibility and legal liability.

\section{RESEARCH DESIGN}

\section{Methodology}

This study is based on the results of two surveys - one of accounting professors teaching auditing and the other of practicing accountants. The academic survey was a web-based questionnaire transmitted in July 2005 . The request to participate in the 2005 survey, which explained the study and provided the link to the online survey, was emailed to all USA faculty indicating an interest in auditing as evidenced by Hasselback's 2005-2006 Accounting 
Faculty Directory. The survey remained open for 30 days for recipients of the email to participate in the survey, and multiple responses from the same respondent were not allowed.

The second survey was sent by email to practicing accountants across the United States. The email addresses were collected through internet sources as well as state society of CPAs' directories. The request to participate in the survey was emailed in June of 2006, the survey remained open for 30 days for recipients of the email to participate in the survey, and multiple responses from the same respondent were not allowed.

Both surveys used identical questions asking the recipients to indicate the importance of the same 41 auditing topics. The questionnaire surveyed topics covered in leading auditing textbooks in 2005-2006 such as Arens et al., 2006; Louwers et al., 2005; and Messier et al., 2006. In the survey, respondents were asked to rate the importance of 41 auditing topics on a Likert scale from 1 (not important) to 5 (very important). The advantages of using a Likert scale are its ease of use and, even though the data are ordinal, the ability to calculate mean responses. The rankings of the importance of the topics are determined from the mean responses to each question.

\section{Demographics}

Table 1 shows response rates and respondent demographics. Demographic information was collected to determine the work experience, education, and certification status for respondents.

A total of 179 usable responses were received from accounting professors and 139 from practicing accountants. This represented response rates of 14.1 percent and 16.1 percent for academics and practitioners, respectively. These response rates are low but Web based surveys yield lower response rates compared to other modes. (Manfreda et al., 2008)

The table shows that both types of respondents have significant experience in their work area. The mean years the accounting professors taught auditing is 12.6 and 93 percent of them had professional accounting experience with a mean number of years experience of 5.6. The mean number of years work experience for the accounting practitioners is 19.3 . For the practitioners, 37 percent indicated their primary work area was auditing and 63 percent in other areas of accounting. Professional certification is also well represented in both groups. For the academics, 92.2 percent hold a professional certification while 98.6 percent of the practicing accountants are certified. The CPA certification is the most represented with 93.9 percent of certified academics holding the CPA and 99.3 percent of the certified practitioners are CPAs. Other certifications represented in the survey are CMA, CIA, CISA, CGFM, CFE, CBA, CBM, CPCU, CRP, CSEP, CFSA, and CVA. Both groups are well represented in academic degrees held as well. The highest degree held for the professors is doctorate, 78.5 percent, and masters, 21.5 percent. For practitioners, the highest degree held is bachelors, 73.4 percent, masters, 25.9 percent, and doctorate, 0.7 percent. Both groups show significant amounts of education and experience in their chosen professions to offer informed opinions.

\section{RESULTS AND DISCUSSION}

Table 2 reports the mean response for the 41 topics in rank order of highest to lowest based on the accounting professors' responses. Table 3 reports the mean response for the 41 topics in rank order of highest to lowest based on the accounting practitioners' responses. Table 4 reports the statistical differences between the two groups of respondents. Statistical differences in Table 4 are determined by two-sided t-tests. A nonparametric test for correlation between the two sets of rankings was also conducted. Using the rankings from Tables 2 and 3, a significant difference between the two sets of rankings was tested for using Spearman's rho rank order coefficients. The rankings between the two surveys are significantly different $\left(\mathrm{r}_{\mathrm{s}}=.897, \mathrm{p}=.000\right)$.

The five most important topics as ranked by accounting professors are audit risk, understanding internal control, evidence, financial statement assertions, and fraud awareness. The five most important topics as ranked by accounting practitioners are audit risk, ethics, documentation, understanding IC, and analytical procedures.

The five topics with the largest significant difference that were ranked higher by academics are 
understanding internal control, the standard audit report, audit risk, evidence, and financial statement assertions. The five topics with the largest significant difference that are ranked higher by practitioners are the study of governmental/NGO standards, history of auditing, assurance services, tests of controls for the finance and investment cycle, and substantive tests for the finance and investment cycle.

Table 5 groups the topics into similar categories. The groups given the most importance by the academic respondents are internal control, audit reports, topics related to the planning phase of the audit, fraud, and substantive testing. The groups given the most importance by the practitioner respondents are topics related to the planning phase of the audit, internal control, fraud, audit reports, and IT auditing.

Fraud awareness was viewed as a much more important topic by academics than by practitioners, while practitioners rated the study of fraud techniques as much more important. The mean response for fraud awareness by professors is 4.74 and 4.51 by practitioners, which is significant $(\mathrm{p}=.000)$. For fraud techniques, the mean ratings are 3.99 and 4.26 for academics and practitioners, respectively, which is also significant ( $\mathrm{p}=.005)$. This shows that professors believe it is important for students to gain a general understanding and awareness of fraud but believe less time should be spent on studying specific techniques to search for fraud. Practitioners seem to want the emphasis on learning actual fraud auditing techniques. It may be that professors believe that learning fraud techniques is a specialized topic and should be covered in depth in a separate fraud examination course.

Topics related to internal control are ranked as more important by academics than practitioners. This is true for all three topics in this category. Topics assessing control risk, reports on internal control, and understanding internal control are rated 4.70, 4.22, and 4.90, respectively, for academics and 4.47, 4.08, and 4.63, respectively, by practitioners. The results for assessing control risk and understanding internal control are significant $(\mathrm{p}=.000$ for both). With the role weak controls played in the massive fraud cases of recent years, and the requirements of the Sarbanes-Oxley Act of 2002, it is not surprising that internal control topics are highly rated by both groups, but academics believe more emphasis should be given to the study of internal control than do practitioners.

IT auditing is considered a much less important topic to be included in an auditing class by academics than by practitioners. The mean rating is 3.63 by academics and 4.04 by practitioners and is significant $(\mathrm{p}=.000)$. This difference may be a result of professors believing that IT auditing is a specialized topic and should be covered in depth in a separate course.

Topics related to planning the audit were considered very important to both groups. Topics in this category were ranked among the top five by both groups. For academics, the mean ratings for analytical procedures, audit risk, documentation, evidence, financial statement assertions, materiality, and planning and administration are 4.61, $4.90,4.11,4.83,4.78,4.72$, and 4.24, respectively. For practitioners, the mean ratings for analytical procedures, audit risk, documentation, evidence, financial statement assertions, materiality, and planning and administration are $4.59,4.67,4.64,4.58,4.49,4.47$, and 4.34, respectively. All of these results were significant ( $\mathrm{p}=.000$ for all) except for analytical procedures $(\mathrm{p}=.688)$ and planning and administration $(\mathrm{p}=.247)$. For the topics with significant differences, academics rated audit risk, evidence, financial statement assertions, and materiality higher than practitioners, while practitioners rank documentation higher than academics. Given the fact that a significant amount of total audit hours are devoted to planning issues, it is not a surprise that these topics are considered very important by both groups. However, it is interesting to note that practitioners place more importance for students to learn documentation, a mechanical process, rather than the audit risk, evidence, materiality, and assertions which develop the theory for the very core of auditing.

The audit reports group of topics are tied with internal control as the most important topics as ranked by academics, while practitioners ranked audit reports as the fourth most important group of topics. The topics of standard report and report modifications are rated 4.71 and 4.51 by academics and 4.30 and 4.25 by practitioners, respectively. These results are significant $(\mathrm{p}=.000$ and $\mathrm{p}=.001)$. Besides the fact that the audit report is important because it is the output of an audit, many professors may rank it high because they choose to cover the topic early in the auditing course so the topic of audit reports can be integrated into the remaining topics in the course. Practitioners may view the topic as requiring nothing more than looking up the correct report form and its format in the firm's audit manual. 
The sampling topics are rated among the least important by both groups of respondents, although rated higher by practitioners. Attribute sampling, PPS sampling, non-statistical sampling, and variables sampling are rated by academics and practitioners, respectively, as 3.78, 3.46, 3.50, 3.15, and 3.80, 3.65, 3.72, 3.67. Significant differences are reported for PPS sampling ( $\mathrm{p}=.073)$, non-statistical sampling ( $\mathrm{p}=.022)$, and variables sampling $(\mathrm{p}=.000)$, with practitioners ranking each topic higher than academics. Academics may rate sampling topics as less important because of the widespread use of sampling software and they feel students need less class time on the topic.

The group means for the auditing standards group of topics are a less useful measure of the importance of this topic because of the disparate rankings of the topics within this group. The auditing standards group of topics includes domestic standards, governmental/NGO standards, and international standards. The ratings for domestic, governmental/NGO, and international standards are 4.69, 2.56, and 3.03 for academics respectively, and 4.49, 3.48, and 3.16 for practitioners, respectively. These results are significant for domestic standards $(\mathrm{p}=.001)$ with academics rating the topic higher and for governmental/NGO $(\mathrm{p}=.000)$ with practitioners rating the topic higher. Accounting professors and practitioners appear to believe the study of domestic standards is very important, with both groups of respondents ranking it among the top ten topics. Governmental/NGO standards and international standards are ranked in the lowest three of all 41 topics by both academics and practitioners. The ranking of the importance of governmental/NGO standards by both groups may be due to more accounting programs adding separate governmental/NGO courses and the study of governmental/NGO auditing standards is viewed as part of that class. The low ranking of the study of international auditing standards may be a result of the USA centric view of most Americans.

Both respondent groups rated the substantive testing and tests of controls topics very similarly. For the substantive testing group, the topics acquisition cycle, finance and investment cycle, payroll cycle, production cycle, and revenue cycle, are rated by academics as $3.96,3.30,3.29,3.53$, and 4.35 , respectively, and rated by practitioners as $3.98,3.97,3.93,3.94$, and 4.09 , respectively. Practitioners rated the finance and investment cycle $(\mathrm{p}=.000)$, payroll cycle $(\mathrm{p}=.000)$, and production cycle $(\mathrm{p}=.000)$ significantly higher than academics. Academics rated the revenue cycle significantly higher than practitioners $(\mathrm{p}=.002)$. For the tests of controls group, the topics acquisition cycle, finance and investment cycle, payroll cycle, production cycle, and revenue cycle, are rated by academics as 3.92, 3.25 3.36, 3.54, and 4.24, respectively, and rated by practitioners as 3.91, 3.97, 3.91, 3.91, and 4.17, respectively. Practitioners rated the finance and investment cycle $(\mathrm{p}=.000)$, payroll cycle $(\mathrm{p}=.000)$, and production cycle $(\mathrm{p}=.000)$ significantly higher than academics. These results clearly show that both academics and practitioners agree that the study of the revenue cycle, for both control testing and substantive testing, is more important than any of the other cycles. For the other cycles besides revenue, both respondent groups seem to believe they are much less important as they ranked the topics near or among the lower half of the topical ratings.

Topics grouped in the "other topics" category have no common thread. However, there are some interesting differences between the two surveys for some of these topics. Professional ethics is highly ranked by both groups, ranked tenth by academics and second by practitioners. The study of assurance services, the auditing profession, certification requirements, history of auditing, and internal auditing are ranked significantly higher in all cases by practitioners ( $\mathrm{p}=.000$ for each topic). The legal liability of auditors is ranked significantly higher by practitioners $(\mathrm{p}=.010)$ as is compliance auditing $(\mathrm{p}=.003)$. There is no significant difference in the rating of the topic subsequent events and it is ranked in the top 18 items by both groups.

\section{SUMMARY AND CONCLUSION}

This study reports the results of a survey of auditing professors and practicing accountants regarding the importance of 41 topics typically included in the first college or university auditing class. The results are based on 179 responses from auditing professors and 139 responses from practicing accountants. Auditing professors and accounting practitioners show significant differences in terms of the importance placed on most of the topics in the survey. The academics rated audit risk, understanding internal control, evidence, financial statement assertions, and fraud awareness as the most important topics in an auditing class. The practitioners five most important topics are audit risk, ethics, documentation, understanding internal control, and analytical procedures. 
The topics rated higher by academics with significant differences are understanding internal control, standard audit report, audit risk, evidence, financial statement assertions, fraud awareness, materiality, assessing control risk, report modifications, domestic auditing standards, and substantive tests-revenue cycle. The topics rated higher by practitioners with significant differences are governmental/NGO standards, history, assurance services, tests of controls-finance and investment cycle, substantive tests-finance and investment cycle, documentation, substantive tests-payroll cycle, internal auditing, tests of controls-payroll cycle, variables sampling, information systems auditing, substantive tests-production cycle, certification, tests of controls-production cycle, the auditing profession, compliance auditing, fraud techniques, and legal liability.

Professors teaching college and university level auditing classes face a challenge insuring they prepare students to enter the business world equipped with all the knowledge and skills necessary to be successful. With the business environment changing quickly with emerging technology and global markets, the proliferation of new standards, and the 150 hours requirement for the CPA exam, professors must use all resources available to offer the most relevant courses available to their students. Practicing accountants have valuable opinions on what should be taught in auditing classes because they know and observe first hand on a daily basis what skills are needed to be successful in the profession. This paper shows the insights of practitioners regarding the importance of topics in the first auditing class and shows where those views differ with auditing professors.

The results of this survey show that practitioners place more emphasis on topics dealing with the practice of auditing (e.g., documentation, fraud techniques, tests of controls, substantive testing, etc.) while academics place more emphasis on topics that form the theory upon which the practice of auditing is built (e.g., audit risk, understanding internal control, financial statement assertions, fraud awareness, etc.). Auditing is more than just acquiring the ability to conduct mechanical tests. To be a successful auditor, not only practical skills are needed but understanding the underlining theory is also required. Auditors need to be able to interpret the results of the auditing tests and be able to more than just record the evidence found. They also must be able to evaluate the evidence in light of the overall audit. The optimal auditing class is one that can provide students with the underlying theory but also with enough skills and techniques to succeed in their first job. That is the most important job of an accounting professor - choosing the appropriate blend of theory and practice to be included in their class.

Auditing professors should not, though, immediately adjust their classes based on the responses from practitioners. Some of the differences may be explained by academics ranking topics lower because they believe the study of that topic should be or is included in other classes in the curriculum. However, the results should not be entirely disregarded either. Practitioners took an auditing class in their course of study at a university and then went out and forged a career in accounting. So they have experienced the educational process as well as applying it to the real world. As well they see the strengths and weaknesses of new hires that work around them. Auditing professors should give serious consideration to tapping into this wealth of knowledge provided by accounting professionals and reevaluate the emphasis in their current auditing class.

\section{AUTHOR INFORMATION}

Jack Armitage is a professor of accounting at the University of Nebraska at Omaha. Dr. Armitage teaches accounting at both the undergraduate and graduate levels with his primary teaching areas in auditing and financial accounting. His primary research areas are auditing and accounting education and he has published over 25 articles in academic and professional accounting journals. Dr. Armitage has significant experience working with academicians and practitioners outside the USA. He has taught classes at foreign universities, consulted on curriculum, participated in roundtables for practicing auditors and accountants, and conducted research in foreign countries.

Jillian Poyzer graduated with a bachelor's degree from Oklahoma Christian University in May of 2004 and received a master's degree in accounting from the University of Nebraska, Omaha in August of 2006. She gained valuable accounting and business experience working for Devon Energy during her undergraduate program and with the Nebraska Business Development Center as a graduate assistant. Currently, Jillian is a senior tax accountant at BKD, LLP in Omaha, NE. She received her CPA license in September of 2008 and is a member of the Nebraska Society of CPAs and the AIPCA. 


\section{REFERENCES}

1. Albrecht, W.S. and R.J. Sack 2000. Accounting Education: Charting the Course Through a Perilous Future. Sarasota, FL: AAA.

2. Arens, A.A., R.J. Elder, and M. Beaseley. 2006. Auditing and Assurance Services: An Integrated Approach, $11^{\text {th }}$ ed. Englewood Cliffs, NJ: Prentice Hall.

3. Bryan, B.J. and L.M. Smith. 1997. Faculty perspectives of auditing topics. Issues in Accounting Education (Spring), 12(1), 1-14.

4. Engle, T. and R. Elam. 1985. The status of collegiate auditing education. Issues in Accounting Education, 97-108.

5. Gorman, J,F. and J.M Hargadon. 2005. Accounting Futures: Healthy Markets for a Time-Honored Profession. Journal of Financial Service Professionals (Jan 2005): 74-79.

6. Gramling, A.A., J.W. Schatzberg, and W.A. Wallace. 1996. The role of undergraduate auditing coursework in reducing the expectations gap. Issues in Accounting Education (Spring), 11(1), 131-161.

7. Johnson, E.N., J. Baird, P. Caster, W.N. Dilla, C.E. Earley, and T.J. Louwers. 2003. Challenges to Audit Education for the 21st Century: A Survey of Curricula, Course Content, and Delivery Methods. Issues in Accounting Education (Aug 2003): 241-263.

8. Louwers, T.J., R.J. Ramsay, D.H. Sinason, and J.R. Strawser. 2005. Auditing \& Assurance Services. Boston, MA: McGraw-Hill Irwin.

9. Manfreda, K. L., M. Bosnjak, J. Berzelak, I. Haas, and V. Vehovar. 2008. International Journal of Market Research, 59(1), 79-104.

10. McCartney, M.W., R.E. Marden, and L.P. Adair. 2002. Topical coverage in internal auditing: Academic versus practitioner perceptions. Accounting Education, 11(4), 311-329.

11. Messier, W.F., S.M. Glover, and D.F. Prawitt. 2006. Auditing \& Assurance Services: A Systematic Approach, $4^{\text {th }}$ ed. Boston, MA: McGraw-Hill Irwin.

12. Novin, A.M. 1997. Education for careers in management accounting, auditing, and tax: A comparison. Journal of Education for Business (Sep/Oct), 73(1), 6p.

Table 1:

Response Rates and Demographics

\begin{tabular}{|l|c|c|}
\hline & Academics & Practitioners \\
\hline Response Rate & & 865 \\
\hline Total Sample & 1274 & 139 \\
\hline Usable Responces Received & $17.1 \%$ & \\
\hline Response Rate & & \\
\hline & & $16.1 \%$ \\
\hline Work Experience & 12.6 & 9.3 \\
\hline Years Taught Auditing (mean years) & 5.6 & $98.6 \%$ \\
\hline Accounting Work Experience (mean years) & & \\
\hline & $92.2 \%$ & $73.4 \%$ \\
\hline Certification Held & & $25.9 \%$ \\
\hline & & $0.7 \%$ \\
\hline Highest Degree Held & & \\
\hline Bachelors & $21.5 \%$ & \\
\hline Masters & $78.5 \%$ & \\
\hline Doctorate & & \\
\hline & & \\
\hline Primary Work Area for Practitioners & & \\
\hline Auditing & & \\
\hline Other areas of accounting & & \\
\hline
\end{tabular}


Table 2

Academics Rankings of Importance

\begin{tabular}{|c|c|c|c|}
\hline \multirow{2}{*}{ Rank } & \multirow{2}{*}{ Topic } & \multicolumn{2}{|c|}{ Academics } \\
\hline & & Mean & Std. Dev. \\
\hline 1 & Audit Risk & 4.90 & 0.302 \\
\hline 2 & Understanding IC & 4.90 & 0.320 \\
\hline 3 & Evidence & 4.83 & 0.408 \\
\hline 4 & Fin Stmt Assertions & 4.78 & 0.504 \\
\hline 5 & Fraud Awareness & 4.74 & 0.453 \\
\hline 6 & Materiality & 4.72 & 0.509 \\
\hline 7 & Standard Report & 4.71 & 0.571 \\
\hline 8 & Assessing Control Risk & 4.70 & 0.505 \\
\hline 9 & Domestic Standards & 4.69 & 0.497 \\
\hline 10 & Ethics & 4.66 & 0.654 \\
\hline 11 & Analytical Procedures & 4.61 & 0.592 \\
\hline 12 & Report Modifications & 4.51 & 0.702 \\
\hline 13 & Sub Tests-Revenue Cycle & 4.35 & 0.828 \\
\hline 14 & Planning \& Admin & 4.24 & 0.819 \\
\hline 15 & Test of Controls-Revenue Cycle & 4.24 & 0.791 \\
\hline 16 & Reports on Internal Cont & 4.22 & 0.791 \\
\hline 17 & Subsequent Events & 4.16 & 0.748 \\
\hline 18 & Documentation & 4.11 & 0.962 \\
\hline 19 & Fraud Techniques & 3.99 & 0.892 \\
\hline 20 & Sub Tests-Acquisition Cycle & 3.96 & 1.008 \\
\hline 21 & Legal Liability & 3.95 & 0.902 \\
\hline 22 & Test of Controls-Acquisition Cycle & 3.92 & 0.920 \\
\hline 23 & Attribute Sampling & 3.78 & 1.015 \\
\hline 24 & Compliance Auditing & 3.76 & 0.934 \\
\hline 25 & Info Systems Auditing & 3.63 & 1.010 \\
\hline 26 & Test of Controls-Production Cycle & 3.54 & 1.022 \\
\hline 27 & Sub Tests-Production Cycle & 3.53 & 1.092 \\
\hline 28 & Certification Requirements & 3.50 & 1.103 \\
\hline 29 & Non-Stat Sampling & 3.50 & 0.960 \\
\hline 30 & PPS Sampling & 3.46 & 1.066 \\
\hline 31 & Auditing Profession & 3.42 & 0.957 \\
\hline 32 & Test of Controls-Payroll Cycle & 3.36 & 1.184 \\
\hline 33 & Sub Tests-Fin\&Invest Cycle & 3.30 & 1.189 \\
\hline 34 & Sub Tests-Payroll Cycle & 3.29 & 1.205 \\
\hline 35 & Internal Auditing & 3.26 & 1.047 \\
\hline 36 & Test of Controls-Fin\&Invest Cycle & 3.25 & 1.142 \\
\hline 37 & Assurance Services & 3.20 & 1.024 \\
\hline 38 & Variables Sampling & 3.15 & 1.144 \\
\hline 39 & International Standards & 3.03 & 1.081 \\
\hline 40 & History & 2.68 & 0.927 \\
\hline 41 & Govt/NGO Standards & 2.56 & 1.102 \\
\hline
\end{tabular}


Table 3

Practitioners Rankings of Importance

\begin{tabular}{|c|c|c|c|}
\hline \multirow{3}{*}{ Rank } & \multirow{3}{*}{ Topic } & \multirow{2}{*}{\multicolumn{2}{|c|}{ Practitioners }} \\
\hline & & & \\
\hline & & Mean & Std. Dev. \\
\hline 1 & Audit Risk & 4.67 & 0.503 \\
\hline 2 & Ethics & 4.66 & 0.560 \\
\hline 3 & Documentation & 4.64 & 0.526 \\
\hline 4 & Understanding IC & 4.63 & 0.515 \\
\hline 5 & Analytical Procedures & 4.59 & 0.551 \\
\hline 6 & Evidence & 4.58 & 0.510 \\
\hline 7 & Fraud Awareness & 4.51 & 0.570 \\
\hline 8 & Fin Stmt Assertions & 4.49 & 0.570 \\
\hline 9 & Domestic Standards & 4.49 & 0.655 \\
\hline 10 & Assessing Control Risk & 4.47 & 0.631 \\
\hline 11 & Materiality & 4.47 & 0.630 \\
\hline 12 & Planning \& Admin & 4.34 & 0.701 \\
\hline 13 & Standard Report & 4.30 & 0.681 \\
\hline 14 & Fraud Techniques & 4.26 & 0.728 \\
\hline 15 & Report Modifications & 4.25 & 0.723 \\
\hline 16 & Legal Liability & 4.20 & 0.746 \\
\hline 17 & Test of Controls-Revenue Cycle & 4.17 & 0.664 \\
\hline 18 & Subsequent Events & 4.12 & 0.651 \\
\hline 19 & Sub Tests-Revenue Cycle & 4.09 & 0.614 \\
\hline 20 & Reports on IC & 4.08 & 0.835 \\
\hline 21 & Compliance Auditing & 4.05 & 0.731 \\
\hline 22 & Info Systems Auditing & 4.04 & 0.693 \\
\hline 23 & Sub Tests-Acquisition Cycle & 3.98 & 0.626 \\
\hline 24 & Sub Tests-Fin\&Invest Cycle & 3.97 & 0.672 \\
\hline 25 & Test of Controls-Fin\&Invest Cycle & 3.97 & 0.732 \\
\hline 26 & Certification Requirements & 3.94 & 0.852 \\
\hline 27 & Sub Tests-Production Cycle & 3.94 & 0.637 \\
\hline 28 & Sub Tests-Payroll Cycle & 3.93 & 0.621 \\
\hline 29 & Test of Controls-Acquisition Cycle & 3.91 & 0.727 \\
\hline 30 & Test of Controls-Production Cycle & 3.91 & 0.647 \\
\hline 31 & Test of Controls-Payroll Cycle & 3.91 & 0.712 \\
\hline 32 & Assurance Services & 3.87 & 0.626 \\
\hline 33 & Attribute Sampling & 3.80 & 0.706 \\
\hline 34 & Internal Auditing & 3.79 & 0.823 \\
\hline 35 & Auditing Profession & 3.78 & 0.752 \\
\hline 36 & Non-Stat Sampling & 3.72 & 0.743 \\
\hline 37 & Variables Sampling & 3.67 & 0.728 \\
\hline 38 & PPS Sampling & 3.65 & 0.749 \\
\hline 39 & Govt/NGO Standards & 3.48 & 0.881 \\
\hline 40 & History & 3.46 & 0.816 \\
\hline 41 & International Standards & 3.16 & 0.968 \\
\hline
\end{tabular}


Table 4

T Test for Equality of Means

\begin{tabular}{|c|c|c|c|c|c|}
\hline Topic & $\begin{array}{c}\text { Academics } \\
\text { Mean }\end{array}$ & $\begin{array}{c}\text { Practitioners } \\
\text { Mean }\end{array}$ & $\mathbf{t}$ & df & $\begin{array}{c}\text { Sig. } \\
\text { (2-tailed) }\end{array}$ \\
\hline Analytical Procedures & 4.61 & 4.59 & 0.402 & 313 & 0.688 \\
\hline Assessing Control Risk & 4.70 & 4.47 & 3.583 & 311 & 0.000 \\
\hline Assurance Services & 3.20 & 3.87 & -6.761 & 308 & 0.000 \\
\hline Attribute Sampling & 3.78 & 3.80 & -0.160 & 314 & 0.873 \\
\hline Audit Risk & 4.90 & 4.67 & 5.088 & 314 & 0.000 \\
\hline Auditing Profession & 3.42 & 3.78 & -3.619 & 313 & 0.000 \\
\hline Certification Requirements & 3.50 & 3.94 & -3.912 & 313 & 0.000 \\
\hline Compliance Auditing & 3.76 & 4.05 & -2.998 & 310 & 0.003 \\
\hline Documentation & 4.11 & 4.64 & -5.780 & 314 & 0.000 \\
\hline Domestic Standards & 4.69 & 4.49 & 3.218 & 311 & 0.001 \\
\hline Ethics & 4.66 & 4.66 & 0.050 & 314 & 0.960 \\
\hline Evidence & 4.83 & 4.58 & 4.879 & 316 & 0.000 \\
\hline Fin Stmt Assertions & 4.78 & 4.49 & 4.716 & 313 & 0.000 \\
\hline Fraud Awareness & 4.74 & 4.51 & 3.939 & 308 & 0.000 \\
\hline Fraud Techniques & 3.99 & 4.26 & -2.844 & 312 & 0.005 \\
\hline Govt/NGO Standards & 2.56 & 3.48 & -7.975 & 315 & 0.000 \\
\hline History & 2.68 & 3.46 & -7.829 & 310 & 0.000 \\
\hline Info Systems Auditing & 3.63 & 4.04 & -4.143 & 313 & 0.000 \\
\hline Internal Auditing & 3.26 & 3.79 & -4.864 & 312 & 0.000 \\
\hline International Standards & 3.03 & 3.16 & -1.070 & 313 & 0.286 \\
\hline Legal Liability & 3.95 & 4.20 & -2.609 & 311 & 0.010 \\
\hline Materiality & 4.72 & 4.47 & 3.903 & 315 & 0.000 \\
\hline Non-Stat Sampling & 3.50 & 3.72 & -2.298 & 313 & 0.022 \\
\hline Planning \& Admin & 4.24 & 4.34 & -1.160 & 313 & 0.247 \\
\hline PPS Sampling & 3.46 & 3.65 & -1.797 & 314 & 0.073 \\
\hline Report Modifications & 4.51 & 4.25 & 3.248 & 312 & 0.001 \\
\hline Reports on IC & 4.22 & 4.08 & 1.572 & 311 & 0.117 \\
\hline Standard Report & 4.71 & 4.30 & 5.682 & 305 & 0.000 \\
\hline Sub Tests-Acquisition Cycle & 3.96 & 3.98 & -0.178 & 311 & 0.859 \\
\hline Sub Tests-Fin\&Invest Cycle & 3.30 & 3.97 & -5.932 & 310 & 0.000 \\
\hline Sub Tests-Payroll Cycle & 3.29 & 3.93 & -5.698 & 308 & 0.000 \\
\hline Sub Tests-Production Cycle & 3.53 & 3.94 & -3.969 & 309 & 0.000 \\
\hline Sub Tests-Revenue Cycle & 4.35 & 4.09 & 3.049 & 310 & 0.002 \\
\hline Subsequent Events & 4.16 & 4.12 & 0.487 & 310 & 0.627 \\
\hline Test of Controls-Acquisition Cycle & 3.92 & 3.91 & 0.022 & 315 & 0.983 \\
\hline Test of Controls-Fin\&Invest Cycle & 3.25 & 3.97 & -6.356 & 310 & 0.000 \\
\hline Test of Controls-Payroll Cycle & 3.36 & 3.91 & -4.863 & 312 & 0.000 \\
\hline Test of Controls-Production Cycle & 3.54 & 3.91 & -3.701 & 312 & 0.000 \\
\hline Test of Controls-Revenue Cycle & 4.24 & 4.17 & 0.845 & 311 & 0.399 \\
\hline Understanding IC & 4.90 & 4.63 & 5.733 & 313 & 0.000 \\
\hline Variables Sampling & 3.15 & 3.67 & -4.653 & 313 & 0.000 \\
\hline
\end{tabular}


Table 5

Importance of Topics by Category

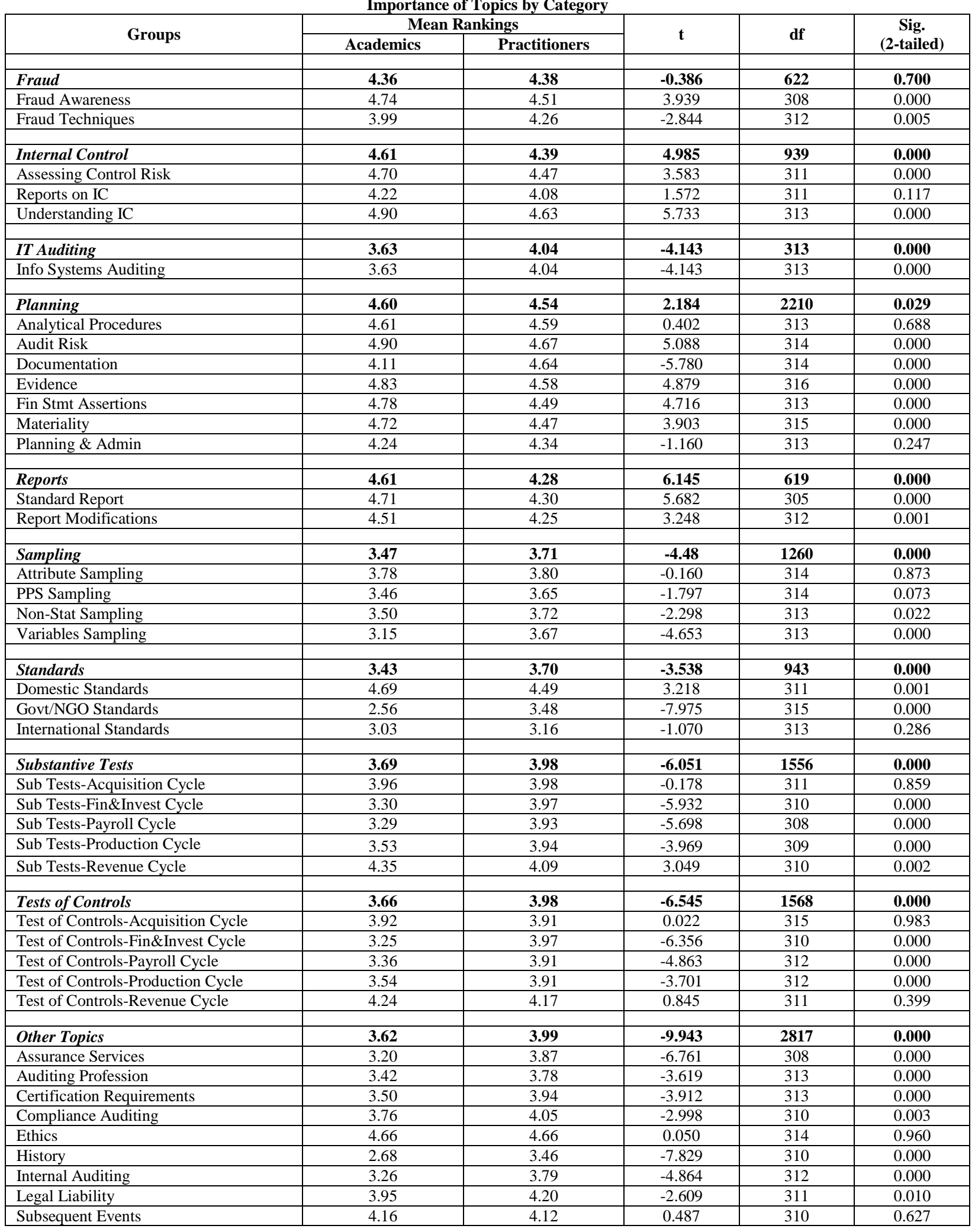


NOTES 